\title{
Nota do organizador
}

A feitura deste dossiê temático é resultado dos recursos advindos da Chamada Pública Proesp no002/2011, urdida pelo Instituto de Pesquisa Econômica Aplicada (IPEA), destinada à seleção de propostas para incentivo à elaboração de um amplo e atualizado painel do estado das artes nos vários campos temáticos das ciências humanas. Em face da aprovação do projeto Cultura e desenvolvimento: $o$ advento da economia criativa, submetido à referida chamada pública, passou-se a elaborar, a partir do $2^{\mathrm{o}}$ semestre de 2012, junto à Revista Latitude (Revista do Programa de Pós-Graduação em Sociologia da Universidade Federal de Alagoas PPGS/UFAL) e à Editora da Universidade Federal de Alagoas (EDUFAL), o planejamento do eixo empírico que galvanizou a consecução deste dossiê: reunir dez artigos acerca das relações entre o conceito/tema de economia criativa e as suas interfaces com histórico binômio cultura e desenvolvimento. Para tanto, foram encomendados artigos a professores, pesquisadores e estudantes, em distintas fases das suas carreiras, mas todos atualizados e envolvidos diretamente com os temas supracitados. Com efeito, o que se segue traz, de modo pormenorizado e abrangente, reflexões as mais diversas, que esposam perspectivas teóricometodológicas distintas entre si. Digno de nota, quanto a esse aspecto, é a contribuição do Grupo de Pesquisa Cultura, Memória e Desenvolvimento (CMD/CNPq), que, há mais de dez anos, tem se ocupado das diversas faces empíricas que ora aproximam as relações entre cultura e desenvolvimento, no Brasil.

O tema/conceito de economia criativa é uma ampliação da noção de indústrias criativas, que emergiu na segunda metade dos anos 90 do XX, como resultado dos trânsitos relacionais entre as escolas de negócios (notadamente os cursos de administração, economia, marketing e direito, de onde saíram os principais teóricos, os consultores e os assessores do tema), alguns governos nacionais (sobretudo o governo australiano e inglês) e as agências transnacionais do sistema ONU (destacadamente a UNCTAD e a UNESCO). Esses agentes, conforme suas posições políticas e as suas missões institucionais, passaram a difundir e aplicar o conceito/tema como forma de traduzir as relações entre cultura e mercado e, simultaneamente, criar e inspirar politicas que permitissem a criação e a profusão de novos negócios culturais, segundo o rastro histórico-estrutural de transformação das relações entre arte, técnica e mercado. Com efeito, o conceito/tema de economia criativa enfatiza a criação de valor simbólico-econômico a partir dos processos criativos e da capacidade intelectual, materializada em bens, serviços e atividades, notadamente as atividades artístico-culturais e os diversos 
segmentos que, hoje, as envolvem e as ultrapassam. Nesses termos, o tema/conceito de economia criativa passou a se inscreve no panorama das relações entre o domínio estético-expressivo e o domínio econômico-comercial, que têm organizado e estruturado as relações entre a produção simbólico-cultural, os processos criativos artístico-culturais e os seus distintos mercados culturais, desde o final do século XX. Nas últimas duas décadas, esses feixes de relações têm formado uma amalgama indissolúvel, que, produz, simultaneamente, valores econômicos e simbólicos, decidindo as estratégias de empresas e conglomerados de comunicação e cultura; instituições governamentais; organizações transacionais; entidades da sociedade civil global e organizações não governamentais (ONGs). As formas de tradução, os distintos usos e as múltiplas acomodações do conceito/tema de economia criativa ao contexto político-institucional brasileiro têm pressionado e complexificado as relações entre cultura e desenvolvimento (cada vez mais, pensa-se em cultura para o desenvolvimento) e, sincronicamente, têm deslocado para o centro da agenda governamental os impactos econômicos oriundos da esfera simbólica, cada vez mais povoada por uma miríade de bens, serviços e atividades culturais. Esse é o lastro empírico geral que ancora e dá sustentação aos trabalhos aqui alinhavados. A partir dessa plataforma, as investigações tomam caminhos distintos, mas complementares.

Como corolário, os trabalhos coligidos neste dossiê tanto chamam atenção para a densidade empírica assumida pela produção, pela circulação e pelo consumo cultural no Brasil contemporâneo (como é caso do trabalho de Frederico Barbosa e Elder P. Maia Alves), quanto evidenciam e exploram as estratégias, os usos e os interesses em torno da criatividade (como é o caso do trabalho de Miqueli Michetti e de João Domingues). Os trabalhos não se complementam apenas nesses dois aspectos, há outros. Por exemplo, os trabalhos de Salete Nery e Miqueli Michetti iluminam aspectos da mesma regularidade e constatação empírica: a moda brasileira tem construído e consolidado a imagem/conceito de uma expressão que se pretende inteiramente singular, caudatária da diversidade cultural advinda dos fazeres e saberes das expressões da cultura popular brasileira. A condução da reflexão e as respostas de problematização fornecidas pelas autoras fornecem insumos para a análise contida no trabalho de Elder P. Maia Alves e Carlos Alexandre de Carvalho Souza. O processo criativo e discursivo presente na moda, no design, na arquitetura e na gastronomia brasileira da última década tem imprimido um acento muito especial ao tema/valor da diversidade cultural, cujo repositório, para grande parte dos criadores envolvidos com esses segmentos (estilistas, desenhistas, projetistas, designs, artistas plásticos, chefes, etc.) é a chamada cultura popular tradicional. Esses criadores, amparados na justificativa político-institucional do tema/conceito da economia criativa, difundido e legitimado por entidades como o SEBRAE, a FIRJAN e o Ministério da Cultura (MINC), atuam como tradutores especializados autorizados da tradição, dando vida a bens simbólico- 
materiais que incorporam e materializam aquilo que os autores chamaram de marcas da brasilidade. Do mesmo modo, o trabalho de Edson Farias, com a sua visada sócio-histórica de longa duração, ilumina e é, simultaneamente, iluminado pelo trabalho de Frederico Barbosa, cujo objetivo último é problematizar e, ao mesmo tempo, fornecer um indicador político-econômico para a economia da cultura e para a economia criativa. A mesma contribuição mútua pode ser imputada aos trabalhos de Gárdia Rodrigues e Gustavo Vale, que delineiam objetos bastante específicos. A primeira, mira o processo de interpenetração recente do mercado de cinema e de televisão, no Brasil, encetado pelo funcionamento do Fundo Setorial do Audiovisual (FSA) e pela aprovação e aplicação da Lei 12.485 (Lei da TV por assinatura); o segundo, aborda a dinâmica de consolidação de um dos mais importantes festivais de cinema do Brasil (o Festival Internacional de Cinema e Vídeo Ambiental de Goiás (FICA), impactado pelo processo de crescimento dos festivais especializados (objeto de políticas de turismo e cultura Brasil afora), mas, sobretudo, afetado pela crescente diferenciação e expansão do mercado brasileiro do audiovisual, muito em razão dos dois mecanismos apontados e explorados no trabalho de Gárdia Rodrigues. Por seu turno, o trabalho de Alessandra Meleiro e Fábio Fonseca desvela e descreve as especificidades globais do conceito de economia criativa, fornecendo insumos para os trabalhos de Elder P. Maia Alves e Carlos Souza, mas também confirmando parte das hipótese vicejadas por Edson Farias e João Domingues.

Muitas outras interfaces poderiam ser apontadas entre os artigos presentes nesta publicação, no entanto, o agente mais autorizado e mais capaz de fazê-las é o próprio leitor deste dossiê. Fica, contudo, assinalado, nesta nota, o juízo interpretativo de que, definitivamente, não é mais possível ignorar as implicações políticas, econômicas e culturais de um tema tão candente e sinuoso quanto o da economia criativa e de toda a sua família conceitual: indústrias criativas, classes criativas, cidades criativas, territórios criativos e capital criativo.

Elder P. Maia Alves

Latitude, vol. 6, n², 2012. 